\title{
Making Nautical Tourism Greener in the Mediterranean
}

\author{
Ani Trstenjak ${ }^{1}$, Saša Žiković ${ }^{1, *(1)}$ and Hoda Mansour ${ }^{2}$ \\ 1 Faculty of Economics and Business, University of Rijeka, 51000 Rijeka, Croatia; ani.trstenjak@ri.t-com.hr \\ 2 College of Business Administration, University of Business and Technology, Jeddah 21577, Saudi Arabia; \\ h.mansour@ubt.edu.sa \\ * Correspondence: sasa.zikovic@efri.hr
}

Received: 20 July 2020; Accepted: 17 August 2020; Published: 18 August 2020

\begin{abstract}
We analyze the elements determining the sustainability of nautical tourism in selected Mediterranean countries (Croatia, Slovenia, Greece, Italy and Turkey). The purpose of our research is to investigate the main obstacles to greater application of renewable energy sources (RES) as the basis for the sustainability of nautical tourism. The obtained results provide valuable information that can help companies and policy makers choose appropriate strategies to achieve the EU 2030 sustainability goals in this sector. Our survey among charter companies was conducted during 2018 on a sample of 51 respondents. We conclude that there is a serious lack of knowledge among nautical tourism respondents regarding the availability of financial instruments from EU funds intended for increasing energy efficiency and adoption of RES. Respondents were familiar with general measures to reduce energy costs but are not familiar with the measures and opportunities provided by available European funds. Our results confirm previous research indicating that significant savings in energy consumption can be achieved by using RES (especially photovoltaic (PV) modules) and that insufficient financial resources and lack of knowledge are the main obstacles to achieving higher adoption rates of RES and increasing energy efficiency in nautical tourism.
\end{abstract}

Keywords: sustainability; nautical tourism; charter; yachting; renewable energy sources; energy efficiency

\section{Introduction}

Tourism is one of the largest and fastest growing industries in the world. In the long run, the basic indicators and trends in the industry, up until 2020, are strong and continue to show a steady upward trend. Of course, this trend was interrupted in 2020 due to the global COVID-19 virus pandemic, but assuming victory over the pandemic, the historical trends should continue. For many economies, tourism revenues are the main source of income, where a skillfully run and well-promoted tourism industry offers a multitude of jobs and supports the local economy. The main representatives of such economies in Europe are Croatia and Greece, where $24.9 \%$ and $20.6 \%$ of GDP is tied to tourism, respectively (2018) [1]. For the industry itself, as well as for the regions that depend on tourism, it is important to manage and develop it in accordance with the principles of sustainable development. The sustainability paradigm is not just a momentary fashion, since tourism can also create many problems for society, such as economic dependence, lack of investing in new technologies and environmental harm [2]. EU policies are based on comprehensive and environmentally oriented management. The main pillars are conservation of resources, gathering of all relevant information and sharing of responsibilities among all participants in order to create a foundation for sustainable tourism development with the minimum possible negative environmental impacts. 


\subsection{Background of Investigations}

In 2019, tourism had a global market share of $10.3 \%$ of income and $10.4 \%$ of total employment [3]. In the OECD countries, figures stand at $4.4 \%$ of GDP and $6.5 \%$ of employment [4]. For an economic sector of this magnitude, the environmental concert is growing in importance. The goals of sustainable tourism are the following [5]: to raise awareness of tourism's contribution to the economy and the environment, to support equality in development (state support for regional development), to maintain the quality of life of the host country and to provide quality services to consumers. Agenda 21 includes tourism as one of the key sectors that needs special attention to achieve sustainability with emphasis on information exchange, awareness, application of innovative practices, supporting sustainable development models and strong emphasis on environmental protection. With regards to the energy pillar of sustainable development, energy efficiency should be promoted by energy efficiency technologies and the penetration of renewable energy sources (RES), as well as by encouraging a demand management program that will contribute to cost internalization using targeted economic instruments [6]. The use of RES in tourism can consequently reduce dependence on imported fuels using domestic resources, provide access to "green" financing through favorable loans or tax incentives and attract more environmentally responsible tourists generating an overall lower environmental impact. Furthermore, on a wider level, such an approach can reduce installed electricity capacity and overall energy needs, as well as create additional employment opportunities associated with the use of renewables $[2,7]$.

The EU strategy aims to direct European society towards a model of sustainable economic development and low $\mathrm{CO} 2$ emissions through a wide range of tools and directives. These tools include: The Integrated Product Policy-IPP, the requirements of Eco-design—Energy-using Products—EuP, the Waste of Electric and Electronic Equipment-WEEE), the Eco-Management and Audit Scheme-EMAS and with regards to our particular topic, the 2003/44/EC Directive on the approximation of the laws, regulations and administrative provisions of the Member States relating to recreational watercraft.

It is possible to identify three integrated issues that characterize the eco-design process applied in the yachting industry [8]:

- Ergonomics - the capacity to enhance the interaction between people and technology, promoting a fuller relationship with nature and with the sea, allowing a boat to create a logical continuum with the mainland;

- Aesthetics - the degree of artistic customization of internal and external areas.

- Innovative Design - following specific goals:

- Reduce resource consumption, by restricting the materials used for construction. Using eco-efficient products and services with equal quality of performance;

- Reduce energy consumption, improving the energy efficiency of vessels;

- Use modular design in order to enable the reuse of materials and recycling;

- Use design "for everyone", providing space and services for people with disabilities.

EU 2030 targets were defined under the 2030 climate and energy framework adopted by the European Council in October 2014 [9]. The targets for renewables and energy efficiency were revised upwards in 2018, and currently amount to:

- $\quad 40 \%$ cuts in greenhouse gas emissions (from 1990 levels)

- $32 \%$ share for renewable energy

- $32.5 \%$ improvement in energy efficiency.

We consider the concept of sustainable development in the framework of tourism, which has gone through several developmental stages to date; this development process has been going on since the 1990s. The economic, environmental, ecological, energy and socio-cultural components 
of tourism sustainability are crucial for the modern concept of sustainable development, where RES represent a strong supporting pillar. Special attention should be paid to promoting solutions that lead to low-carbon development of countries and the participation of the tourism sector in the implementation of environmental protection strategies. Encouraging faster economic growth based on market integration and institutional reforms, higher employment rates and promoting sustainable development are major strategic goals for any national economy [10].

\subsection{Current State of Knowledge about Sustainable Tourism Including Nautical Tourism}

Over the last decade, tourism was one of the fastest growing sectors of the world economy and its effects on the local economy have been significant. Tourism plays a key role in global economic activity, generating jobs and creating added value. Current measures and programs are in favor of increasing the quality and efficiency of investments in tourism with the aim of increasing added value [11]. One of the key activities in achieving the sustainability of tourism and local community development is to consider future economic, environmental and social impacts. Numerous studies indicate increased energy consumption in tourism activities with a significant impact on the environment, e.g., [12-14]. The promotion of sustainable development and the implementation of these activities can be based on the use of RES, in particular solar and wind energy. However, ineffective legal frameworks or an absence of national programs and standards for the use and development of RES can discourage implementation [15].

In the Mediterranean, yacht-related manufacturing, services and infrastructure show high importance for local economies and communities [16]. Identifying sustainability indicators (SI) for small and medium enterprises (SMEs) related to the yachting industry is important for assessing and implementing their sustainability strategies, which in turn can be critical for their future market success. Hojnik et al. [17] investigate the most suitable sustainability indicators for SMEs operating in the yachting industry and its related three business sectors (yacht-related service sector, yacht-related manufacturing and yacht-related maritime infrastructure). They define a list of 33 SIs for yacht-related services, 38 SIs for manufacturing and 38 SIs for maritime infrastructure, categorized according to both the triple bottom line and the operational indicator typology that entails input, process, output and outcome-oriented indicators.

Lam-Gonzalzes [18] investigated factors determining the international growth of SMEs dedicated to nautical activities in the context of island destinations, thus contributing to defining a profile of the nautical tourism firms with greater international performance. Their results validate a universal model that explains the causes of international growth of tourism-based SMEs dedicated to nautical activities but also incorporates under-investigated firm level variables as well as socio-psychological ones. Out of these variables, motivational aspects and the perceptions of managers regarding the potentialities of their enterprises improve the explanatory power of their international growth model.

Scheepens et al. [19] apply the life cycle assessment-based Eco-costs Value Ratio (EVR) model to analyze potential negative environmental effects of business initiatives on a system level, and provide a theoretical approach to the design of sustainable business models by means of a three dimensional approach of costs, eco-costs and market value. They apply two methods applied for analysis and design: Eco-efficient Value Creation (EVR benchmarking) and the Circular Transition Framework (describing stakeholder activities which are required for the transition towards sustainable business models). They suggest that the approach of Eco-efficient Value Creation helps to avoid many pitfalls of the design of circular business models (e.g., having a positive result on the product level, but having a negative effect on the societal level, or having a positive effect on the environment but also having insufficient customer perceived value to overcome fierce market competition).

Schmitt [20] points to an important issue that nautical tourism, although considered as being "high quality" tourism is by no means sustainable or green and the quality part refers only to the prestige and the financial power associated with this form of tourism. By not transforming nautical tourism towards sustainability and green outcomes, our society risks repeating the same mass tourism 
development mistakes. Cerchiello [21] builds on the same premise while analyzing the economic and social impacts of nautical tourism in Spain. It is true that nautical tourism has significant economic benefits and generates a lot of employment and favors the deseasonalization of the tourist activity. Unfortunately, an increase in boat traffic contributes to greenhouse gases (GHG) emissions, water pollution and massive anchoring near coasts; all of these impacts can destroy the sea flora and fauna, putting yachting in collision with local fishing and classical tourist industries.

At the moment, RES are the most suitable form of energy for the concept of a clean environment that does not pollute during the production of organic matter and reduces the cost of energy needs. More that this, RES represent a reference to modern lifestyle, and in order to use RES in the tourism sector efficiently, it is necessary to take into account available resources and capacities. Electric motors in general are becoming more valued not only in the car industry, but also by designers and users of smaller vessels. In practical terms, the main perceived advantage for users of electric over internal combustion engines is actually not the zero emissions aspect but rather their low noise level. In many cities with waterfronts, there is a trend of "returning to water". Numerous restaurants, cafes, cultural and entertainment centers are located in post-port areas or other places related to or close to the water. In order to add value to such locations, there is an increasing trend of prohibiting traffic in the rest and recreation zones for vessels powered by high power internal combustion engines [12].

In places without electricity, photovoltaic (PV) systems in combination with energy storage solutions are technologically reliable solutions for electricity supply in existing or planned forms of tourist offers. Despite their demanding designs, the use of PV modules on boats and various other types of vessels is becoming more frequent. Before installing a module, it is necessary to take into account economic viability as well as the fulfilment of necessary technical and functional prerequisites. Carli et al. [22] develop a model for optimal energy scheduling of a PV-battery storage microgrid for a nautical marina. They show that wider proliferation of RES does not represent only a change in the power source but a shift in paradigm from "generation follows load" to the new paradigm of "load follows generation". This paradigm shift in energy generation has led to the development of Demand Side Management. Demand Side Management generally indicates a set of actions aimed at efficiently controlling and managing energy consumption of a unit/site, primarily to decrease electricity costs, including network and system charges, but also to reduce the need for investments in networks and power generation for meeting peak demand [23]. Demand Side Management actions are aimed at modifying the characteristics/patterns of energy consumption in order to bring the energy demand and supply closer together [24]. In its basic form of implementation, a detailed analysis of energy consumption of a unit (e.g., a vessel, building, facility, zone, etc.) determines the specificities of each unit, as does understanding whether the consumption habits can be modified without the use of additional resources [25]. The on-site installation of renewable sources such as PV panels that can be installed on vessels, as well as energy storage systems (e.g., electrochemical, thermal storages), also known as distributed power generation and battery storage, leads to reduced environmental impacts while improving security of supply [26]. Scheepens et al. [19] shows that addition of the nautical tourism services to the water recreation system has a positive economic effect, but is unsustainable in terms of environmental impact on a system level, due to the use of diesel internal combustion engines in motor yachts. To avoid further environmental deterioration, nautical tourism must be converted into a sustainable business model through the introduction of sustainable yachts using renewable energy for propulsion and applying sustainable materials. Scheepens et al. shows that replacing the diesel technology in rental motor yachts with electric propulsion (which results in an overall eco-costs reduction of over $50 \%$ ) is essential to convert the motor yachts business model into a sustainable solution.

Contrary to these developing global trends, we noticed that a surprisingly small number of charter vessels have installed PV modules on them. Bohdanowicz et al. [7] investigated uncertificated virtuous practices by asking companies in the yachting sector to indicate which sustainability measures they employ. The following answers were provided [8]: 
- Adoption of technological tools for saving water (6.6\%);

- Adoption of technological tools for saving energy (10.0\%);

- Separated waste collection $(73.3 \%)$;

- Use of renewable energy sources (13.3\%);

- Green procurement (6.6\%).

Their results show a weak diffusion of company practices geared towards sustainability, with only waste collection being an outlier. With the latest trends and improvements in RES, this aspect deserves much more attention. The interesting question is why are serious investments and adoption practices lacking even though all the technological and investment pre requirements are present.

The potential reasons for this could be numerous and a number of authors have investigated this phenomenon e.g., [27-33]. Mirza et al. [27] categorize RES adoption barriers into six groups: policy and regulatory barriers, institutional barriers, fiscal and financial barriers, market-related barriers, technological barriers and information and social barriers. Luthra et al. [29] categorize barriers into seven groups: Economical \& Financial; Market; Awareness \& Information; Technical; Ecological and Geographical; Cultural \& Behavioral; and Political \& Government Issues. Ghimirea et al. [31] categorize RES adoption barriers into six groups: social, policy and political, technical, economic, administrative and geographic. Besides financial and administrative/regulatory barriers, the majority of authors also identify social/information barriers as a key hindrance to the wider adoption of RES in SMEs.

The purpose of our research is to investigate the main obstacles to greater application of RES as the basis for the sustainability of nautical tourism. Our goal is to determine key driving factors behind relatively low adoption rate of RES in the charter industry and nautical tourism. Furthermore, we aim to show that investments in RES, while satisfying the social and environmental criteria for investments, are at the same time also very profitable for the investor. The installation of PV modules reduces the consumption of fossil fuels in the engine drive, decreasing greenhouse gas (GHG) emissions and increases savings, i.e., income for the investor throughout the life of the project.

\section{Methodology}

Based on the purpose of our research, we used a questionnaire as the main instrument for collecting data in the survey design. In order to fulfill the goal of our research, we focused on three drivers identified by the aforementioned authors: financial conditions, administrative barriers and awareness/information regarding RES and possibilities for its use. We assumed that low awareness and lack of knowledge regarding the benefits of installing PV modules on vessels is one of the key causes behind the low adoption rate of RES in the charter industry and nautical tourism.

We conducted our survey by sending the questionnaire to 193 addresses of various charter companies in Croatia and other countries in the Mediterranean (Croatia 143, Greece 25, Italy 10, Turkey 9 and Slovenia 6) during November 2018 [34]. Charter companies are business contacts from the company Yacht Rent and they all include small and medium enterprises (SME) in nautical tourism which provide accommodation service on charter vessels. The number of questionnaires sent corresponds to the number of charter companies in each country. Questionnaires were mostly sent to companies in Croatia since Croatia has the biggest fleet in the world and a proportional number of SMEs. According to the Croatian Ministry of Sea, Transport and Infrastructure and Croatian Register of Shipping [35,36] Croatia is a major power in the nautical charter services and it makes up $40 \%$ of the global nautical charter fleet. The data provided by the Maritime Affairs and Transport Ministry shows that a total of 2762 companies are registered as businesses which rent out vessels, and 930 of them are active. In 2019, 1956 sailing boats were offered for rent, plus 2166 sailing yachts and 256 motor yachts.

The questionnaire was completed by 51 respondents ( 41 in Croatia, 5 in Greece, 2 in Italy, 2 in Slovenia and 1 in Turkey), representing a return of $26.4 \%$.

The first part of the questionnaire contains basic demographic characteristics: gender, age, country of employment, job description and level of education. The second part of the questionnaire 
contains questions related to energy efficiency in nautical tourism companies, the number of installed PV modules on vessels, possible savings in fossil fuel consumption using PV modules based on self-assessment, the level of knowledge of measures to reduce energy costs, knowledge of measures to increase energy efficiency, obstacles to achieving a higher level of energy efficiency as well as proposals and suggestions related to this research. All survey questions were closed and mandatory except for the last question, where respondents had the opportunity to list suggestions related to our research.

The first step in planning the installation of PV modules is assessing the daily electricity needs of a vessel, as well as the insolation potential of the area where the solar panels will be installed. The insolation potential of the geographical area can be estimated based on the given parameters and the solar calculator. By selecting the geographical location and nominal power of the PV modules, it is possible to calculate the average insolation potential of the selected area-in our case the Adriatic Sea [37]. To determine the energy needed for the electrical equipment, the following steps are conducted [38]:

(1) identifying the equipment and its energy consumption,

(2) determining the operational duration of each equipment,

(3) determining the total energy required, and

(4) categorizing every piece of electrical equipment and summarizing its total energy consumption based on each category.

The formula to estimate the required energy is as follows:

$$
\text { Total energy } E=P \times t \times n
$$

where $E$ is total energy (Wh), $t$ is operational duration (h), $P$ is power $(\mathrm{W})$, and $n$ is the number of equipment.

Most marine PV systems consist of three main components: electricity-producing PV modules, a charge regulator that regulates the charging of the battery and prevents overcharging, and a battery that stores the energy generated by the PV modules. The energy created in this way is used to power the devices that use direct current (DC) as a power source such as lights, pumps, fans, etc., as well as devices that use alternating current (AC) such as TVs, radios, satellite dishes, microwave ovens, etc. An inverter or converter is a separate unit that converts 12 volts $(\mathrm{V})$ of current to the $120 \mathrm{~V}$ required to operate AC devices on board. The application of solar energy and the development of marine solar systems have a strong perspective and clear benefits for the development within the nautical tourist offer. The possibilities of applying solar systems in nautical sector are numerous and economic cost-effectiveness analysis is crucial in choosing an adequate solar system. It is also necessary to minimize all potential problems and difficulties in installing and running such solar systems on vessels.

The basis for our financial analysis was a PV module of $100 \mathrm{~W}$, meaning that such a PV module will generate 3500 watt hours (Wh: a unit for measuring the power or electrical effect of an electric current in a specific unit of time required for the operation of a device; a $100 \mathrm{~W}$ device consumes $100 \mathrm{Wh}$ of electricity in $1 \mathrm{~h}$ ) of energy per week $(100 \mathrm{~W} \times 7$ days $\times 5 \mathrm{~h})$, which can be used to run several devices and electrical devices in that period. When estimating the amount of energy that will be needed, it is necessary to add up the need for electricity of each individual appliance (lights, pumps, electronics, etc.) that are usually used during the day. It is necessary to multiply the nominal power of each device (e.g., the average power of one lamp is $60 \mathrm{~W}$ ) with the average time of use of that device (e.g., $3 \mathrm{~h}$, giving $60 \mathrm{~W} \times 3 \mathrm{~h}=180 \mathrm{Wh}$ ). All obtained values are summed and divided by the number of hours per day that PV modules are charging, i.e., $5 \mathrm{~h}$. The amount obtained represents the amount of solar energy needed to prevent complete discharge of the ship's batteries. The amount of energy produced by a $100 \mathrm{~W}$ PV module can be expressed as: expected power/week $=3500 \mathrm{Wh}$ [39-41]. Average daily consumption of DC devices on a typical vessel are presented in Table 1. 
Table 1. Average daily consumption of direct current (DC) devices on board (Wh).

\begin{tabular}{lcccc}
\hline Device & Amperes & Hours of Use & Amperes Tot & Wh \\
\hline Cabin lights & 2 & 3 & 6 & 72 \\
\hline Cooling system & 5 & 10 & 50 & 600 \\
\hline Outdoor lighting & 1 & 8 & 8 & 96 \\
\hline Electronics/VHF & $1 / 2$ & 6 & 3 & 48 \\
\hline TOTAL & \multicolumn{5}{c}{ Source: Authors. }
\end{tabular}

The table shows that the main energy devices that consumers use are the cooling system and outdoor lighting, with the longest usage time expressed in hours of use. Taking into account all the above consumers on board and after estimating the consumption of each of the devices, the operational performance of PV modules at different daily insolation must also be taken into account.

Integrating the PV system into the vessel's electricity grid has recently become an important strategy for saving energy and reducing greenhouse gas emissions from vessels. Due to the close link between the energy obtained from the PV system and ship navigation plans, including the planned location, navigation routes, and time, a feasibility study of PV system integrated into the vessel's electricity grid is very important. It is necessary to conduct a comprehensive technical and economic analysis as well as an environmental impact assessment. Previous research results show that the hybrid power system has a high level of financial feasibility and environmental performance [41]. By installing PV modules on vessels, it is possible to achieve savings in fuel consumption of $4-5 \%$, and the amount of energy savings varies depending on the number of operating hours, engine power, and the power factor [42]. The last part of our analysis-financial feasibility of the PV installation project-was based on classical corporate finance tools used in the evaluation of investment projects. We calculated the coverage ratio, economic efficiency, coverage contribution rate, safe margin, net cash flow, net present value (NPV), internal rate of return (IRR), and modified internal rate of return (MIRR).

\section{Results}

The structure of the respondents and characteristics of the charter management of the surveyed companies are presented in Table 2.

Table 2. Characteristics of the survey respondents from different countries.

\begin{tabular}{llccccc}
\hline \multirow{2}{*}{ Number of companies } & & Croatia & Greece & Slovenia & Italy & Turkey \\
\hline Gender & & 41 & 5 & 2 & 2 & 1 \\
\hline \multirow{2}{*}{ Age } & Male & 15 & $/$ & $/$ & 1 & 1 \\
& Female & 26 & 5 & 2 & 1 & $/$ \\
\hline \multirow{5}{*}{ Working position } & $26-35$ & 21 & 2 & $/$ & $/$ & $/$ \\
& $36-45$ & 8 & 1 & 2 & $/$ & $/$ \\
& $46-55$ & 8 & 1 & $/$ & 2 & 1 \\
& $>56$ & 4 & 1 & $/$ & $/$ & $/$ \\
\hline \multirow{5}{*}{ Education } & Owner & 8 & 1 & 1 & 2 & 1 \\
& Manager & 14 & 3 & $/$ & $/$ & $/$ \\
& Employee & 18 & 1 & 1 & $/$ & $/$ \\
& Authorized officer & 1 & $/$ & $/$ & $/$ & $/$ \\
\hline & PhD & $/$ & $/$ & $/$ & 1 & $/$ \\
& MBA & 6 & 1 & 1 & $/$ & 1 \\
& Master's degree & 18 & 3 & $/$ & $/$ & $/$ \\
& Bachelor's degree & 12 & 1 & $/$ & 1 & $/$ \\
\hline
\end{tabular}

Source: Authors' survey. 
Considering the demographic characteristics, 34 female respondents $(66.7 \%)$ and 17 male respondents $(33.3 \%)$ participated in the research. In the 25-35 years age group, there were 23 respondents $(45.1 \%), 11$ respondents in the $35-45$ years group $(21.6 \%), 12$ respondents $(23.5 \%)$ in the $45-55$ years group, and 5 respondents in the over 55 years group $(9.8 \%)$. Looking at the educational level structure, 6 respondents have a vocational/high school education (11.8\%), 14 respondents have a university bachelor's degree (27.5\%), 21 respondents have a university master's degree $(41.2 \%)$ and 9 respondents have a MBA degree (17.6\%). Only one respondent has the highest level of education with a completed $\mathrm{PhD}(2 \%)$. Charter companies' characteristics and perception of PV modules are presented in Table 3.

Table 3. Characteristics of surveyed charter companies and perceptions of photovoltaic (PV) modules.

\begin{tabular}{lcccccc}
\hline & & Croatia & Greece & Slovenia & Italy & Turkey \\
\hline & $1-10$ & 7 & 2 & $/$ & 1 & $/$ \\
& $11-20$ & 12 & 2 & 1 & 1 & $/$ \\
Number of vessels & $21-30$ & 10 & $/$ & $/$ & $/$ & 1 \\
& $31-40$ & 4 & $/$ & $/$ & $/$ & $/$ \\
& $41-50$ & 2 & $/$ & $/$ & $/$ & $/$ \\
& $>51$ & 6 & 1 & 1 & $/$ & $/$ \\
\hline \multirow{3}{*}{ Number of vessels with PV } & 0 & 17 & 1 & 2 & 2 & 1 \\
modules & $1-5$ & 19 & 1 & $/$ & $/$ & $/$ \\
& $6-10$ & 4 & 2 & $/$ & $/$ & $/$ \\
& $11-20$ & $/$ & $/$ & $/$ & $/$ & $/$ \\
Perceived savings in fossil & $>20$ & 1 & 1 & $/$ & $/$ & $/$ \\
fuels due to PV modules & $1-10 \%$ & 22 & 1 & 1 & $/$ & 1 \\
& $21-30 \%$ & 9 & $/$ & $/$ & 1 & $/$ \\
& $31-40 \%$ & 2 & 3 & 1 & $/$ & $/$ \\
& $>41 \%$ & 1 & $/$ & $/$ & $/$ & $/$ \\
\end{tabular}

Source: Authors' survey.

The largest number of respondents (16) own 11-20 vessels (31.4\%) in their charter management, 11 respondents own $21-30$ vessels (21.6\%), 10 respondents own $1-10$ vessels (19.6\%), 8 respondents own $>50$ vessels $(15.7 \%), 4$ respondents own $31-40$ vessels in the fleet $(7.8 \%)$, and only 2 respondents own $41-50$ vessels (3.9\%) in their charter management. From the obtained results, we concluded that the largest number of respondents manage a fleet of 11-20 vessels, while $15.7 \%$ of respondents manage an impressive fleet of more than 51 vessels. According to the survey, 23 respondents $(45.1 \%)$ do not have built-in PV modules on their vessels, 20 respondents (39.2\%) have 1-5 vessels with built-in modules, 6 respondents (11.8\%) have 6-10 vessels with built-in modules, while only 2 respondents (3.9\%) have more than 20 vessels with built-in PV modules.

The last question in this part of the survey looked at the subjectively perceived savings in on-board consumption of fuel due to the installation of PV modules. Almost half of respondents, 25 of them (49\%) correctly believe that the use of PV modules saves 1-10\% in the consumption of fossil fuels.

The level of respondent knowledge and interest in the subject of energy efficiency is presented in Table 4 .

The majority of respondents are familiar with measures to reduce energy costs (47.1\%) but are not familiar with measures to encourage energy efficiency available from EU funds or they want to know more (74.1\%). Respondents see insufficient financial resources (37.3\%) as the biggest obstacle to achieving a higher level of energy efficiency, followed closely by administrative barriers (31.3\%) and a lack of awareness/information (25.5\%). The majority of respondents expressed interest in a short educational meeting (51\%) about the possibilities of using EU funds to increase efficiency of power generation and decrease GHG emissions. 
After presenting results on the level of knowledge of measures to increase energy efficiency and the understanding of perceived obstacles among respondents, we continued with a technical and economic analysis of PV installations on vessels. The calculation and estimation of the insolation potential of a $100 \mathrm{~W}$ PV module is presented in Table 5 below.

Table 4. Level of respondent knowledge of measures to increase energy efficiency.

\begin{tabular}{|c|c|c|c|c|c|c|}
\hline & & Croatia & Greece & Slovenia & Italy & Turkey \\
\hline \multirow{3}{*}{$\begin{array}{l}\text { Are you familiar with } \\
\text { measures to reduce energy } \\
\text { costs and increase energy } \\
\text { efficiency? }\end{array}$} & Yes & 17 & 4 & 1 & 1 & 1 \\
\hline & No & 13 & 1 & 1 & 1 & / \\
\hline & Want to know more & 11 & / & / & / & / \\
\hline \multirow{3}{*}{$\begin{array}{l}\text { Are you familiar with EU } \\
\text { funds and measures to } \\
\text { promote energy efficiency? }\end{array}$} & Yes & 9 & 2 & 1 & 1 & / \\
\hline & No & 19 & 3 & / & 1 & 1 \\
\hline & Want to know more & 13 & / & 1 & / & / \\
\hline \multirow{4}{*}{$\begin{array}{l}\text { Obstacles to achieving a } \\
\text { higher level of energy } \\
\text { efficiency }\end{array}$} & $\begin{array}{l}\text { Insufficient financial } \\
\text { resources }\end{array}$ & 15 & 3 & 1 & / & / \\
\hline & $\begin{array}{l}\text { Complicated } \\
\text { procedures }\end{array}$ & 12 & 2 & 1 & / & 1 \\
\hline & $\begin{array}{l}\text { Unavailable } \\
\text { information }\end{array}$ & 11 & / & / & 2 & I \\
\hline & Other & 3 & & & & \\
\hline \multirow{3}{*}{$\begin{array}{l}\text { Are you interested in a } \\
\text { short educational meeting? }\end{array}$} & Yes & 20 & 4 & 1 & 1 & 1 \\
\hline & No & 3 & / & / & 2 & / \\
\hline & Maybe & 18 & 1 & 1 & / & / \\
\hline
\end{tabular}

Table 5. Estimation of the insulation potential of a $100 \mathrm{~W}$ PV module.

\begin{tabular}{llcccc}
\hline Period of Year & \multicolumn{7}{l}{ Daily Electricity Production in Wh } \\
\hline Number of PV modules & 1 & 2 & 5 & 10 & 20 \\
\hline $\begin{array}{l}\text { The worst period in winter } \\
\text { (peak sunshine hours: } 1.80 \mathrm{~h} \text { ) }\end{array}$ & 180 & 360 & 900 & 1.800 & 3.590 \\
\hline $\begin{array}{l}\text { The best period in summer } \\
\text { (peak sunshine hours: } 5.00 \mathrm{~h} \text { ) }\end{array}$ & 500 & 1000 & 2.500 & 5.000 & 15.000 \\
\hline $\begin{array}{l}\text { Annual average } \\
\text { (peak sunshine hours: } 3.40 \mathrm{~h} \text { ) }\end{array}$ & 340 & 680 & 1.700 & 3.400 & 10.200 \\
\hline Maximum power output in Amperes $(12 \mathrm{~V})$ & 32.05 & 64.11 & 160.27 & 320.55 & 641.10 \\
\hline
\end{tabular}

Source: Authors' calculations based on [26].

The analysis of insolation potential and daily production in Wh shows that the Adriatic Sea has peak insolation in the summer and by applying only one PV module of $100 \mathrm{~W}$, it is possible to achieve a total daily output of $500 \mathrm{Wh}$, while in winter $180 \mathrm{Wh}$ daily can be expected. The annual daily average of 340 Wh meets the anticipated needs of an on-board PV module for a smaller vessel.

Assuming the use of a midsize vessel, but also looking at safety reasons and greater comfort and sailing experience, we planned the installation of a PV module with a total power of $166 \mathrm{~W}$, yielding 830 Wh per day during summer. The main purpose of the PV module was the production of electricity and consumption at the place of production. The produced electricity was intended exclusively for the charging vessel's instruments and batteries and was not intended for delivery to the electricity network. It was assumed that two solar panels with a power of $48 \mathrm{~W}$ and one larger solar panel with a power of $70 \mathrm{~W}$ would be installed, as well as a charging regulator in order to meet daily consumption needs. A total investment horizon of 5 years was assumed. The structure of investment is dominated by the value of equipment (93.9\%), while a significantly smaller part of the investment relates to the cost of 
installing PV modules on the vessel (6.1\%). The service life of all equipment is 10 years, including the charging regulator.

The feasibility of the project is presented in Appendix A Table A1, clearly showing that installing $\mathrm{PV}$ modules on vessels in nautical tourism is very cost-effective. The profitability of the total investment is extremely high at $60.9 \%$. The coverage rate and the economic efficiency are extremely high in the first and last year of the project as well, being 7.62 in the first year and 8.43 in the last year of the project. The coverage contribution rate is $97.7 \%$ and the safety margin is 0.86 . The calculated values show that the planned savings in fossil fuels could be $86 \%$ lower and the project would still not enter negative profitability territory. Net cash flow in all years of the project is positive and sufficient for loan repayment, since the cash flow is higher than the loan annuity. The internal rate of return (IRR) of the project is $82 \%$, the modified internal rate of return (MIRR) is $37 \%$, and the return on investment occurs in the second year of the project.

\section{Discussion and Conclusions}

Looking at the structure of the respondents and characteristics of the charter management of the surveyed companies, females form a predominant group, most likely due to the higher share of women in administrative jobs that dominate nautical tourism. The predominant age group between 25 and 35 indicates a younger staff in charter companies. At the same time, most of the respondents have a university education, i.e., they are highly qualified and educated to perform their work. Considering the organizational level within each company, 20 respondents (39.21\%) are employees, 19 respondents $(37.3 \%)$ occupy a managerial position and 11 respondents $(21.6 \%)$ are company owners, while 1 procurator $(2 \%)$ also participated in the research. Our typical respondent was a university educated female in the 25-35 years age group holding an employee or managerial position.

Characteristics of surveyed charter companies and perception of PV modules showed very intriguing results. Although half of the correspondents correctly believe that the use of PV modules saves $1-10 \%$ of the consumption of fossil fuels, the other half believes in seriously exaggerated figures regarding fuel savings, considering that actual savings are around 5\%. Eleven respondents $(21.6 \%)$ expected savings of $21-30 \%, 10$ respondents (19.6\%) expected savings of $11-20 \%, 3$ respondents $(5.9 \%)$ expected savings amounting to $31-40 \%$ while 2 respondents $(3.9 \%)$ believe that installing PV modules saves $>41 \%$ of fuel consumption.

These results are surprising, since they completely contradict the adoption rate of PV modules on vessels in our sample, which amounts only to $14.3 \%$. If over $50 \%$ of respondents believe that installing PV modules on a vessel can yield savings of at least $11 \%$ of fuel costs, one has to wonder why is the adoption rate of $\mathrm{PV}$ modules is so low.

Respondents from Croatia are mostly familiar with measures to reduce energy costs $(41.5 \%)$ but are not familiar with measures to encourage energy efficiency available using EU funds (46.3\%). They see insufficient financial resources $(36.6 \%)$ as the biggest obstacle to achieving a higher level of energy efficiency and express interest in a short educational meeting $(48.8 \%)$. In Greece, similar to in Croatia, most respondents are familiar with measures to reduce energy costs and increase energy efficiency in general, but are not familiar with measures to encourage energy efficiency available using EU funds. Respondents from Greece also express interest in a short educational meeting while seeing insufficient funding as the biggest problem for achieving a higher level of energy efficiency. Similarly, respondents from Slovenia are familiar with measures to reduce energy costs but are partially familiar with measures to encourage energy efficiency available using EU funds. They also express interest in a short educational meeting, while insufficient funding is also presented as the biggest problem for achieving a higher level of energy efficiency. They also cite complicated procedures as one of the main obstacles. Respondents from Italy were partially acquainted with measures to promote energy efficiency using available EU funds. Insufficient information is also presented as the biggest problem for achieving a higher level of energy efficiency. The respondent from Turkey is not familiar with measures to promote energy efficiency available using EU funds and shows interest in an educational 
meeting. The respondent also cites complicated procedures as an obstacle to achieving a higher level of energy efficiency.

From the presented results, we can conclude that there is a serious lack of awareness and information among nautical tourism respondents regarding the availability of financial resources available using EU funds. Respondents are familiar with general measures to reduce energy costs but are not familiar with the measures and opportunities provided by EU funds to increase the level of energy efficiency. Two main obstacles to implementing energy efficiency measures identified by respondents are a lack of financing and complicated procedures.

More than a quarter (25.5\%) of respondents admit that a lack of awareness and/or information related to RES and their benefits are their main reason for not installing PV modules on ships. Taking into account the human vanity and lack of knowledge on popular topic, the resulting answers seem to be very honest.

Our results follow the conclusions drawn by $[28,30,32,33]$ in the sense that despite being a highly profitable investment, the financial aspect of RES is not enough to promote their wider adaptation in nautical tourism.

Sovacool [28] finds that a gap between how electricity is made and how it is socially perceived perpetuates public apathy and misinformation about RES and has caused its slow adoption in general population and small businesses. Results show that it boils down to the fact that people simply do not comprehend why such technologies may be needed. Owusu et al. [30] identifies lack of information as one of the key factors hindering wider implementation of RES in businesses. Fashina et al. [32] besides the classical financial barriers to wider adoption of RES, identifies as one of the main barriers a lack of information and public awareness, as well as a lack of human capacity and training. Akinwale et al. [33] identify awareness and knowledge about renewable energy, adequate government policies, trust, and peer-effect as key factors influencing adaptation of RES among micro and small enterprises. They conclude that relevant government policies supported by "political will" are necessary to promote the stated factors influencing the willingness to adopt RES. Similar to these studies, we find that awareness and knowledge about RES play a key factor in a wider push for "greener" and more sustainable nautical tourism.

The financial analysis of installing PV modules on a vessel was based on the assessment of the economic and financial flow of the project with the corresponding criteria. The primary goal of the project was to invest in equipment to increase energy efficiency by reducing future expenditure, primarily by reducing fossil fuel procurement costs. Even though we did not have as high an exploitation rate of PV modules as [22], where they report PV plant exploitation to be $92-96 \%$ of its annual production, all economic and financial indicators of the project are positive, even under the worst case scenario. Unfortunately, in modeling the demand side of the microgrid, [22] do not provide a detailed elaboration of the parameters for charging yachts, so we cannot compare the results more thoroughly. The calculated values show that the planned savings in fossil fuels could be $86 \%$ lower and the project would still not enter negative territory. With the assumed unfavorable change of input variables, the project still remained profitable. According to the degree of risk, the project could be assessed as low-risk and according to all other criteria, the project was profitable [38,43-45]. Our results confirm the ones from [19] in that it is not only environmentally friendlier but also very financially profitable to switch to RES in nautical tourism.

Harmonized energy policy and implementation of strategies can increase the level of energy efficiency through the creation and application of models of sustainable tourism and a greater use of RES. There is a connection between sustainable development, responsible tourism, and supply excellence when using RES for transforming energy sources in order to follow the principle of sustainable development. The ecological, energy, socio-cultural, and economic components of sustainability are crucial in the development of the modern concept of sustainable development in tourism. The transition to a low-carbon economy will result in structural changes, and the creation of new services can outweigh 
the economic costs of transition, thereby accelerating economic growth and development that will be economically, environmentally, and socially sustainable.

Policymakers should focus on solving the three issues we identified as being the main obstacles in a greater adoption rate of RES-a lack of awareness and knowledge related to available EU funds intended for achieving sustainable business models and products, attractive financing opportunities for sustainable projects, and complicated bureaucratic procedures. Greater adoption of RES goes a long way but does not solve the sustainability challenge lying ahead for the tourism industry. Future research should focus on other aspects of achieving sustainability in tourism, as it is clear that this will be the main challenge in the upcoming decades.

This study faces various limitations that substantially reduce the potential generalization of its results and the scope of its conclusions. Firstly, it is based on five countries located in the East Mediterranean and therefore there is a need to consider evidence from other alternative nautical destinations. Secondly, the survey focused only on three predominant factors that are usually identified as barriers but for greater clarity, it would be worth analyzing all of the RES implementation barrier factors that are identified in the literature.

Author Contributions: Conceptualization, A.T. and S.Ž.; methodology, A.T. and H.M.; software, A.T.; validation, S.Ž.; formal analysis, A.T. and S.Ž.; investigation, A.T. and H.M.; resources, A.T. and H.M.; writing-original draft preparation, A.T. and S.Ž.; writing-review and editing, A.T., S.Ž. and H.M.; visualization, H.M.; supervision, S.Ž.; project administration, S.Ž.; funding acquisition, S.Ž. and H.M. All authors have read and agreed to the published version of the manuscript.

Funding: This research was funded by University of Rijeka, Croatia grant number uniri-drustv-18-228 and University of Business and Technology, Jeddah, Kingdom of Saudi Arabia.

Conflicts of Interest: The authors declare no conflict of interest. The funders had no role in the design of the study; in the collection, analyses, or interpretation of data; in the writing of the manuscript, or in the decision to publish the results.

\section{Appendix A}

Table A1. Estimation of the financial flow of the project (in $€$ ).

\begin{tabular}{|c|c|c|c|c|c|c|}
\hline Year: & 0 & 1 & 2 & 3 & 4 & 5 \\
\hline Revenues from electricity production & & 1.680 & 1.680 & 1.680 & 1.680 & 1.680 \\
\hline Revenues from structural funds & & 2.393 & - & - & - & - \\
\hline Project terminal value & & - & - & - & - & 1.326 \\
\hline TOTAL INCOME & & 4.073 & 1.680 & 1.680 & 1.680 & 3.007 \\
\hline Investment & 2.520 & & & & & \\
\hline Investment in solar panel $12 \mathrm{~V} 48 \mathrm{~W}$ & 1.604 & & & & & \\
\hline Investment in solar panel $12 \mathrm{~V} 70 \mathrm{~W}$ & 1.003 & & & & & \\
\hline Charging regulator $200 \mathrm{~W}$ & 47 & & & & & \\
\hline TOTAL EXPENDITURES & & 534 & 389 & 378 & 368 & 490 \\
\hline Installation cost & & 96 & - & - & - & - \\
\hline Cost of consumables & & 67 & 27 & 27 & 27 & 27 \\
\hline Maintenance cost & & 53 & 53 & 53 & 53 & 53 \\
\hline Amortization & & 265 & 265 & 265 & 265 & 265 \\
\hline Financial expenses & & 53 & 43 & 33 & 23 & 12 \\
\hline Other expenses & & 40 & 41 & 43 & 44 & 45 \\
\hline
\end{tabular}


Table A1. Cont.

\begin{tabular}{lcccccc}
\hline Year: & $\mathbf{0}$ & $\mathbf{1}$ & $\mathbf{2}$ & $\mathbf{3}$ & $\mathbf{4}$ & $\mathbf{5}$ \\
\hline Gross financial result & & 3.539 & 1291 & 1302 & 1312 & 2650 \\
\hline Taxes (20\%) & & 708 & 258 & 260 & 262 & 530 \\
\hline Net financial result & -2.653 & 3.150 & 1.342 & 1.339 & 1.338 & 2.397 \\
\hline Net cash flow (NCF) & & 300 & 300 & 300 & 300 & 300 \\
\hline Loan annuity & & 2.850 & 1.042 & 1.040 & 1.038 & 2.097 \\
\hline Sufficiency of NCF-liquidity of the project & & & & & \\
\hline Net present value & -2.653 & 3.150 & 1.342 & 1.340 & 1.338 & 3.458 \\
\hline Net cash flow (NCF) & 1 & 0.91 & 0.83 & 0.75 & 0.69 & 0.62 \\
\hline Discount factor 9.87\% & -2.653 & 2.867 & 8.338 & 1.112 & 918 & 2.160 \\
\hline Net present value (NPV) & 1 & 0.69 & 0.48 & 0.33 & 0.23 & 0.16 \\
\hline Discount factor 1.44\% & -2.653 & 2.187 & 447 & 449 & 311 & 559 \\
\hline Net present value (NPV) & -2.653 & 214 & 1.325 & 2.336 & 3.254 & 5.414 \\
\hline Return period & $82 \%$ & & & & & \\
\hline IRR & 1.44 & & & & & \\
\hline & 5.414 & & & & & \\
\hline NPV function & $37 \%$ & & & & & \\
\hline MIRR & & & & & & \\
\hline
\end{tabular}

\section{References}

1. World Data Atlas. Available online: https://knoema.com/atlas/Croatia/topics/Tourism/Travel-and-Touri sm-Total-Contribution-to-GDP/Contribution-of-travel-and-tourism-to-GDP-percent-of-GDP (accessed on 3 May 2020).

2. Dziuba, R. Sustainable Development of Tourism-EU Ecolabel Standards Illustrated Using the Example of Poland. Comp. Econ. Res. 2016, 12, 112-127. [CrossRef]

3. World Travel Tourism Council. Travel E Tourism, Global Economic Impact \& Trends 2020; World Travel Tourism Council: London, UK, 2020. Available online: https://wttc.org/Research/Economic-Impact (accessed on 3 July 2020).

4. Organisation for Economic Co-Operation and Development (OECD). Policy Responses to Coronavirus (COVID-19): Tourism Policy Responses to the Coronavirus (COVID-19). 2020. Available online: https://www.oecd.o $\mathrm{rg} /$ coronavirus/policy-responses/tourism-policy-responses-to-the-coronavirus-covid-19-6466aa20/ (accessed on 4 July 2020).

5. Jugović, A.; Kovačić, M.; Hadžić, A. Sustainable development model for nautical ports. Tour. Hosp. Manag. 2011, 17, 175-186.

6. Menegaki, A.N.; Agiomirgianakis, G.M. Sustainable Technologies in Greek Tourist Accommodation: A Quantitative Review. Eur. Res. Stud. J. 2018, 11, 222-238. [CrossRef]

7. Bohdanowicz, P.; Churie-Kallhauge, A.; Martinac, I.; Rezachek, D. Renewable Energy for Sustainable Tourism; Department of Energy Technology; Department of Regional Planning; Royal Institute of Technology: Stockholm, Sweden, 2011.

8. Pencarelli, T.; Splendiani, S. Imprese turistiche e sostenibilità: Evidenze empiriche nella provincia di Pesaro e Urbino. In Proceedings of the XXXIII Annual Conference of Regional Science (A.I.S.Re.), Rome, Italy, 13-15 September 2012.

9. European Commission (EC). Communication from the Commission to the European Parliament, the Council, the European Economic and Social Committee and the Committee of the Regions A Policy Framework for Climate and Energy in the Period from 2020 to 2030. 2014. Available online: https://eur-lex.europa.eu/legal-content/EN/ALL /?uri=CELEX\%3A52014DC0015 (accessed on 4 July 2020).

10. Klarin, T. Creating a Model of Sustainable Tourism Development in Urban Destinations in Croatia. Ph.D. Thesis, Faculty of Economics and Business, University of Rijeka, Rijeka, Croatia, 2017; pp. 1-397. 
11. OECD. Rethinking tourism success for sustainable growth. In OECD Tourism Trends and Policies 2020. Guidebook; OECD Publishing: Paris, France. Available online: https:/www.oecd-ilibrary.org/urban-rural-an d-regional-development/oecd-tourism-trends-and-policies-2020_82b46508-en (accessed on 20 January 2020).

12. Łapko, A. The use of auxiliary electric motors in boats and sustainable development of nautical tourism-Cost analysis, the advantages and disadvantages of applied solutions. Transp. Res. Procedia 2016, 16, 323-328. [CrossRef]

13. Sperling, K.; Overschie, M.G.F.; Hekkenberg, R.G.; Mulder, K.F. Sustainable technologies in inland navigation-A long term perspective. In Proceedings of the International Conference on Inland Shipping Technology, Wuhan, China, 22 July 2007.

14. Eastlack, E.; Faiss, E.; Sauter, R.; Klingenberg, S.; Witt, M.; Szymanski, S.; Lidqvist, A.; Olsson, P. Zero Emission Super-Yacht. In Proceedings of the Fourteenth International Conference on Ecological Vehicles and Renewable Energies, Monte-Carlo, Monaco, 8-10 May 2019.

15. Calderon-Vargas, F.; Asmat-Campos, D.; Caretro-Anselmo, G. Sustainable Tourism and Renewable Energy: Binomial for Local Development in Cocachimba, Amazonas, Peru. Sustainability 2019, 11, 4891. [CrossRef]

16. Diakomihalis, M.N.; Lagos, D.G. Estimation of the economic impacts of yachting in Greece via the tourism satellite account. Tour. Econ. 2008, 14, 871-887. [CrossRef]

17. Hojnik, J.; Biloslavo, R.; Cicero, L.; Cagnina, M.R. Sustainability indicators for the yachting industry: Empirical conceptualization. J. Clean. Prod. 2020, 249, 119368. [CrossRef]

18. González-Hernández, M.M.; Suárez-Rojas, C.; León, C.J. Factors Constraining International Growth in Nautical Tourism Firms. Sustainability 2019, 11, 6846. [CrossRef]

19. Scheepens, A.; Vogtländer, J.; Brezet, J. Two life cycle assessment (LCA) based methods to analyse and design complex (regional) circular economy systems. Case: Making water tourism more sustainable. J. Clean. Prod. 2016, 114, 257-268. [CrossRef]

20. Schmitt, T. Quality tourism-A sustainable alternative to the development of tourism on Mallorca? Geogr. Z. 2000, 88, 53-65.

21. Cerchiello, G. The sustainability of recreational boating, The case study of anchoring boats in Javea (Alicante). Investig. Tur. 2018, 16, 165-195.

22. Carli, R.; Dotoli, M.; Jantzen, J.; Kristensen, M.; Ben Othman, S. Energy scheduling of a smart microgrid with shared photovoltaic panels and storage: The case of the Ballen marina in Samsø. Energy 2020, 198, 117188. [CrossRef]

23. Palensky, P.; Dietrich, D. Demand Side Management: Demand Response, Intelligent Energy Systems, and Smart Loads. IEEE Trans. Ind. Inform. 2011, 7, 381-388. [CrossRef]

24. Gelazanskas, L.; Gamage, K.A.A. Demand side management in smart grid: A review and proposals for future direction. Sustain. Cities Soc. 2014, 11, 22-30. [CrossRef]

25. Kakran, S.; Chanana, S. Smart operations of smart grids integrated with distributed generation: A review. Renew. Sustain. Energy Rev. 2018, 81, 524-535. [CrossRef]

26. Mathiesen, B.V.; Lund, H.; Connolly, D.; Wenzel, H.; Østergaard, P.A.; Möller, B.; Nielsen, S.; Ridjan, I.; Karnøe, P.; Sperling, K.; et al. Smart Energy Systems for coherent 100\% renewable energy and transport solutions. Appl. Energy 2015, 145, 139-154. [CrossRef]

27. Mirza, U.K.; Ahmad, N.; Harijan, K.; Majeed, T. Identifying and addressing barriers to renewable energy development in Pakistan. Renew. Sustain. Energy Rev. 2019, 13, 927-931. [CrossRef]

28. Sovacool, B.K. The cultural barriers to renewable energy and energy efficiency in the United States. Technol. Soc. 2009, 31, 365-373. [CrossRef]

29. Luthra, S.; Kumar, S.; Garg, D.; Haleem, A. Barriers to renewable/sustainable energy technologies adoption: Indian perspective. Renew. Sustain. Energy Rev. 2015, 41, 762-776. [CrossRef]

30. Owusu, P.A.; Sarkodie, S.A. A review of renewable energy sources, sustainability issues and climate change mitigation. Cogent Eng. 2016, 3, 1167990. [CrossRef]

31. Ghimire, L.P.; Kim, Y.; Kim, Y. An analysis on barriers to renewable energy development in the context of Nepal using AHP. Renew. Energy 2018, 129, 446-456. [CrossRef]

32. Fashina, A.; Mundu, M.; Akiyode, O.O.; Abdullah, L.; Sanni, D.; Ounyesiga, L. The Drivers and Barriers of Renewable Energy Applications and Development in Uganda: A Review. Clean Technol. 2019, 1, 9-39. [CrossRef] 
33. Akinwale, Y.O.; Adepoju, A.O. Factors influencing willingness to adopt renewable energy technologies among micro and small enterprises in Lagos State Nigeria. Int. J. Sustain. Energy Plan. Manag. 2019, 1, $69-82$.

34. Yacht-Rent.com. Available online: www.yacht-rent.com (accessed on 10 January 2018).

35. CRS. Available online: http://www.crs.hr/en-us/home.aspx (accessed on 1 August 2020).

36. MMPI. Available online: https://mmpi.gov.hr/sea/nautics/8462 (accessed on 1 August 2020).

37. ECOWHO. Solar Panels Calculator. Available online: http://www.ecowho.com/tools/solar_power_calculator. php (accessed on 10 March 2020).

38. Sunaryo; Syahrihaddin, A.; Imfianto, P.S. Solar Energy for a Traditional Coastal Fishing Platform. J. Mar. Sci. Appl. 2019, 18, 366-371.

39. Karabuga, A.; Yakut, M.Z.; Yakut, G.; Selbas, R.; Ucgul, I. Renewable Energy Solution for Tourism. Available online: http://eujournal.org/index.php/esj/article/viewFile/5389/5188 (accessed on 1 August 2020).

40. Syafaruddin; Dionisius, G.; Willy, A.F.A. Design of Boat Powered Photovoltaic Systems; Universitas Hasanuddin: Makassar, Indonesia, 2013; Volume 50, pp. 207-214.

41. BoatUS. Boat Owners Association of the United States 2020. What is a Solar Panel and How Does It Work? Available online: https://www.boatus.com/boattech/articles/solar-panels.asp (accessed on 10 January 2020).

42. Qiu, Y.; Chengqing, Y.; Jinrui, T.; Xujing, T. Techno-economic analysis of PV systems integrated into ship power grid: A case study. Energy Convers. Manag. 2019, 198, 111925. [CrossRef]

43. Olgun, K.; Kadir, E.E. Energy Efficiency Optimization Techniques for Solar Powered Boats. In Proceedings of the Second Global Conference on Innovation in Marine Techology and the Future of Maritime Transportation, Bodrum, Turkey, 24-25 October 2016; pp. 356-368.

44. Trstenjak, A. Energy Efficiency in Nautical Tourism in Croatia and Selected Mediterranean Countries. Specialist Thesis, University of Rijeka, Rijeka, Croatia, 2017.

45. Trstenjak, A. Investigation of motivation of employees in the charter enterprises of nautical tourism. Proc. Fac. Econ. East Sarajevo 2015, 11,39-48. [CrossRef]

(C) 2020 by the authors. Licensee MDPI, Basel, Switzerland. This article is an open access article distributed under the terms and conditions of the Creative Commons Attribution (CC BY) license (http://creativecommons.org/licenses/by/4.0/). 